\title{
O QUE NÃO SE DEVOLVE
}

Edmar Monteiro Filho é mestrando da Universidade Estadual de Campinas - UNICAMP, na área de Teoria Literária. É formado em História e Ciências Biológicas, Modalidade Médica. É escritor e poeta com sete títulos publicados, entre conto e poesia. Recebeu diversos prêmios literários na categoria contos, entre os quais Prêmio Guimarães Rosa, da Radio França Internacional, Prêmio Cruz e Souza, da Fundação Catarinense de Cultura, ambos em 1997; Prêmio Cidade de Belo Horizonte, em 1998, e Prêmio Luis Vilela, em 2003.

E-mail: $\underline{\text { edmont @uol.com.br. }}$

Era um cofre de madeira, do tempo em que os cofres não necessitavam dos aços das confianças. Na forma de um barril, a abertura suficiente para moedas de amontoadas curiosidades, a primeira vez de aprender acúmulos, que as coisas poderiam ser para um tempo que ainda não existia. Cofre de madeira sob ameaça de serrotes que eu desconhecia.

A avó: "Um dia (esse dia que ela jamais disse) vai ser seu."

Meu seria o cofre de madeira com relevos em vermelho e verde, desenhos de flores e galhos folhas. $\mathrm{O}$ formato de barril recheado de ruídos que eram só isso, de nada por dentro, que "dentro" não se via. Esse, o cofre que eu queria, pedia com a impaciência moldada nos sorrisos da avó, que me irritavam porque eu não sabia esperar.

Então, esqueci.

Quando chegou o dia, esse que eu não imaginava, minha avó era outra. Não se sentava mais no chão e não condescendia em perder nas damas, eu ensinando as regras a cada nova partida, infância em jogo. Essa melhor avó que começara a me deixar anos antes, deixou-me um cofre. Meu cofre, enfim, quando eu estava desatento. A dimensão dessa promessa que, de repente, se cumpria, a palavra que estivera guardada com velhas moedas. O tempo de minha avó.

Daí, um serrote, porque então havia mais: todo aquele ruído de moedas que eu quisera desde sempre e que compreendia aos 18. Desapareciam relevos por ruídos; o cofre era metal, a madeira perecível sob um tempo de serrotes. Era meu e podia serrar, quebrar, queimar, que o cofre era dentro, por fim. Serrei para destruir o meu desinteresse. O cofre, a gratidão súbita e ruidosa, metal espalhado, jamais imaginar que tantas moedas coubessem numa lembrança.

Moedas. Durante tanto tempo as pratas e cobres e outros presos num cofre de tempo. Havia tantas, mas havia uma só: os mesmos olhos que serraram relevos e galhos verdes, enxergavam o patacão enorme, prata. Do Império. O mais pronto, a ponto do esquecimento de tudo o mais, nessa idade em que a memória não tem maiores paciências. Não havia mais entre tantas o que não fosse aquele patacão de prata do tempo do Império, com todos os relevos vivos, cada um dos valores, caras e coroas.

Eu quis exibi-lo com todas essas formas, mas não teria coragem de furos, que o valor das coisas, isso sim, verdadeira herança de minha avó. Um chaveiro, para as chaves Revista Escrita Rua Marquês de São Vicente, 225 Gávea/ RJ CEP 22453-900 Brasil 
da Mundial, com moldura para não furar a melhor moeda com as melhores chaves da melhor das motos para o meu orgulho. A madeira perecida, virada em aço.

Meu novo chaveiro que girava até a esquina dos meus dezenove anos. Cada jogo de sinuca nas mesas certas do melhor dos clubes da cidade, nas mais saias dos meus desejos, nas aulas que freqüentava por uma educação que não me interessava. Quais amigos? Os melhores. O melhor futebol, festas, a melhor liberdade que a inveja dos demais permitia. $\mathrm{E}$ Cássia, a melhor prata, melhor paixão mais linda de toda descoberta.

Girava assim: as alegrias que não era preciso pedir, essa vida do que era e do que não era tão permitido. Girava assim, até que desaparecesse. A moeda e chaves, sem deixar os vestígios mais que decepção imensa. Um joelho ruim para o futebol. A madeira, depois a prata. Amizades desfalcadas por desvios, mudanças diversas. Até Cássia: não querer mais, porque não, e deixar a cidade com a família, depressa, serra acima.

A mesma esquina, alguns anos depois: eu de vinte e outros metais. Não esperava demais do igual dos meus dias e noites. Esperava de nada. Então, máquina com o ruído dos bons motores, estacionando ao meu lado, com a mulher na garupa, couros. A minha atenção toda e o capacete sem ocultar os sorrisos que eram para mim. Num momento primeiro, desconhecer. Depois, as surpresas:

- Quantos?

- Seis anos?

- Por aí.

Meu companheiro Cícero (copiar a matriz das provas, roubada do quarto de hotel do professor de física). Um abraço para todos os anos passados, sem contato, pelo de mais amigo que aquele fora (disputar a artilharia do campeonato de futebol de salão do clube, em 67). Imediatamente, nossa gíria em desuso, para o riso.

A mulher, desembarcada, serrou seu cofre para revelar o aço: Cássia. Minha Cássia. Meu amigo com Cássia. Era tudo. Um beijo no rosto, de tanto tempo suficiente para todos os cheiros que trocamos em épocas nem tão inocentes. Cícero e Cássia. Bem vindos à esquina do meu tempo perdido.

O que seria permitido: beber, pela coincidência ao lado das mesas de sinuca, nas quais nunca conseguira uma vitória sequer, qualquer taco torto dos que já não havia ali. Nosso primeiro instante: os três sentados ao redor de nossas lembranças.

E enquanto eu redescobria Cássia, revirando uns detalhes despreparados, subitamente sobre a mesa, a melhor prata do Império, no melhor chaveiro que eu tivera há tanto e por tão pouco tempo: meu chaveiro. E com que chaves? Cássia e tudo.

Procurei os bons humores do meu amigo e encontrei muitos, a ponto de imaginar a melhor surpresa de trazer meu chaveiro que eu tanto lamentara perder, como ele sabia. Esperei que um dissesse algo mais. Esperei por ele, agradecido, embora Cássia. Que algo se dissesse ali, para explodir de volta o momento bom de reencontrar um grande amigo, 
Cássia, o cofre de minha avó. Esperei seu brinquedo, divertido. Uma piada do tamanho de tantos anos passados. Esperei para que ele explicasse depois. Esperei.

As conversas de recordações e os modos de Cássia, radiante Cássia. Radiante Cícero, abraçando e levando consigo as horas, saltando um vazio de anos para aterrissar ali, um incômodo invencível.

\section{Esperei.}

Para preencher os espaços soltos do nosso desconhecimento mútuo. O chaveiro sobre a mesa o que mais eu desconhecia. Imaginar onde e por que estivera perdido. Uma brincadeira que se esquecia. Cássia sem qualquer vestígio da estranheza daquilo, que era minha apenas. Cássia que brilhava de sorrir, a mesma sumida desde o mesmo tempo sem que eu recebesse as notícias rareando, depois que se fora.

A simpatia que se esgotava de espera. Uns anos preenchidos depressa, pouco mais de 2 horas sobre a mesa e copos. As chaves que não se moviam de volta aos bons anos, quando amava Cássia e os amigos com o melhor de mim.

Na mão direita de Cícero, recolhidas outra vez as chaves com o brilho dos olhos de Cássia. Os sorrisos naturais, os relevos do Império prontos para voltar de onde haviam chegado, viagem de anos, tornados muitos séculos de desconhecimento. Luvas para o frio da estrada, serra acima, enquanto as chaves rodando nas mãos dela, que tinha medo de moto, que sofria excessivamente com o frio, que adorava as viagens e tudo mais que não comigo. Seu endereço quase próximo que eu jamais soubera.

Daí, um tapa nas costas do contentamento, da fala de antigos companheiros, de Cássia, um beijo no rosto com resto de carinho que eu não podia compreender.

De volta à esquina aos olhos do último abraço, quando os couros, as pratas tocandome num último aperto de mãos das piores brincadeiras cruéis. Meia volta nas chaves para trancar e disparar lembranças. Cássia. Na cintura. Capacetes. O que eu não disse restou quieto, silenciando a noite humilhada. E seria só. O que eu não disse.

Que Cícero levasse de volta para uma terra exaurida uns restos de afeto, decepção, memória estragada das melhores simpatias, para refazer um trajeto seco, vazio. Que ele levasse de volta um vaso quebrado a serrote, pescarias num rio sujo, cheirando a coisa morta. Que levasse no ronco de prata os acenos e sorrisos, despedidas cobertas por capacetes. Que Cícero levasse de volta tantas festas estragadas, as piores notas em provas impossíveis, despencadas janelas de um hotel decadente. Que levasse embora a pior das partidas mal jogadas, violenta fratura exposta.

Essa noite que se estendeu terrível, sem que eu dissesse nada. O que eu não soube que irrompeu numa curva qualquer, a velha moto conduzida pela prata com que minha avó me presenteara desde antes de sua morte. Nessa curva que se interpôs entre as amizades e o pior de tudo. Para Cícero, um braço perdido - o esquerdo - pelas minhas lembranças. Para Cássia, mais, do tamanho da mágoa que eu nem imaginara. Tudo pelo que não se perdoaria 
entre companheiros de colégio, vivos entre todos os melhores momentos do melhor do meu passado.

A moto que vi no pátio da rodoviária, depois do acidente. Cícero como vi, enfim, seus olhos escuros no hospital, seu braço na cintura de Cássia nunca mais. A tristeza que não me capturou enquanto Cássia sobrevivia apenas no carinho de uns anos atrás. Enquanto não se abrisse os cofres a serra, murro, martelo do aço rasgando asfalto, eu iria seguir revendo esse único momento na estrada. E já é hoje, tão depressa.

Lembro-me de uma noite de junho, em 68, no jardim que ainda não se iluminara: Cássia. Depois, contar ao amigo uns beijos e mais. Cícero. Lembro seus melhores olhos e o riso que não foi de pura inveja. 